\title{
Hubungan Pengetahuan Wartawan Dengan Pemberitaan LGBT di Koran Sindo
}

\author{
Dudi Iskandar; Muhamad Isnaini \\ Dosen Fakultas Ilmu Komunikasi Universitas Budi Luhur \\ dudisabiliskanbdar@yahoo.com; m.isnaini@yahoo.com
}

\begin{abstract}
This study focuses on the relationship of religious knowledge and news about LGBT (Lesbian, Gay, Bisexual, and Transgender) in Koran Sindo newspaper. This research based on $L G B T$ as reality which increasingly rampant in everyday. This research used survey method to editor of Koran Sindo by spreading questioner. Editors are the ones who process and authorize to bring down a story, including about LGBT. Based on the research that has been done, it can be drawn conclusion. Firstly, the religious knowledge of the respondents was not influenced by previous religious education, religious routines and understanding of the meaning of reading the Qur'an. Secondly, respondents have a high knowledge of religious knowledge aspect. This is evident from the average score of 26 item of questions that is able to pass the standard weight of 75. Thirdly, respondents also have a higher attitude to objective on the news about LGBT, by high score completeness news, namely 82.5 and writing placement, amounting to 69,6. Fourthly, there is a positive correlation of religious knowledge of the respondents with the news on LGBT. This is proven by hypothesis which statistically reject Ho and accept $\mathrm{Ha}$.
\end{abstract}

Keywords : Journalistic, LGBT, Religion, News

\begin{abstract}
ABSTRAK
Penelitian ini fokus pada hubungan pengetahuan agama dan pemberitaan tentang LGBT (Lesbian, Gay, Bisexual, and Transgender) di Koran Sindo. Penelitian ini berangkat dari realitas LGBT yang kian marak di kehidupan keseharian dan kemudian diangkat menjadi berita oleh media massa, termasuk Koran Sindo. Penelitian ini menggunakan metode survei terhadap redaktur Koran Sindo dengan cara menyebar kuesioner. Redaktur adalah yang mengolah dan berwenang menurunkan sebuah berita, termasuk tentang LGBT. Berdasarkan penelitian yang telah dilakukan, maka dapat ditarik simpulan sebagai berikut. Pertama, pengetahun agama para responden ternyata tidak dipengaruhi oleh pendidikan agama sebelumnya (pesantren/madrasah) rutinitas mengikuti pengajian/taklim, dan pemahaman atas makna bacaan Alquran. Kedua, responden mempunyai pengetahuan yang tinggi menyangkut aspek pengetahuan agama. Hal ini terbukti
\end{abstract}


dari rata-rata skor 26 item pertanyaan yang mampu melewati bobot standar 75 . Ketiga, responden juga punya sikap yang lebih tinggi untuk objektif atas pemberitaan tentang LGBT, yang dibuktinya dari tingginya skor kelengkapan berita, yakni 82,5 dan penempatan tulisan, sebesar 69,6. Keempat, terdapat hubungan/korelasi yang positif pengetahuan agama para responden dengan pemberitaan mengenai LGBT. Hal ini terbukti dengan uji hipotesis yang secara statistik menolak Ho dan menerima Ha.

\section{Kata Kunci : Jurnalistik, LGBT, Agama, Berita}

\section{PENDAHULUAN}

Jurnalistik adalah proses mencari, menemukan, mengolah, dan menyiarkan informasi melalui media massa. Jurnalistik berangkat dari peristiwa. Di dalam peristiwa terdapat banyak fakta. Penyusunan fakta dalam kaidah jurnalitik dikonstruksi dengan kaidah $5 \mathrm{~W}+$ 1H. Setelah itu disebarluaskan ke masyarakat. Inilah yang disebut proses berita. Proses berita melalui tiga tahap, yaitu, produksi, distribusi, dan konsumsi informasi mulai dari peristiwa hingga dikonsumsi masyarakat. Meski demikian sebuah berita di satu media bukan hanya rangkaian fakta yang tersusun menjadi sebuah kalimat dan paragraf. Ia juga merupakan pikiran dan sikap penulis dan asisten redaktur serta redaktur atau produser. Minimal segala latar belakang sosial budaya, pergaulan, dan pendidikan wartawan sangat memengaruhi bagaimana fakta dikonstruksi dalam sebuah berita.

Tidak semua peristiwa bisa dibuat berita. Semuanya tergantung sudut pandang yang mau diambil oleh redaksi yang keputusannya ditentukan oleh kebijakan redaksi (Tebba, 2005:150). Wartawan yang berada di lapangan hanyalah mencari fakta dari sebuah peristiwa. Sedangkan editor hanyalah merapikan berita. Di sinilah peran redaktur sebuah surat kabar, misalnya, sangat menentukan pemuatan dan penempatan sebuah berita Mereka tidak bisa menentukan berita yang dibuatnya ditampilkan di dalam media. Sebab keputusan pemuatan berita ditentukan oleh kebijakan redaksi yang tercermin dalam rapat redaksi. Dengan demikian, kebijakan redaksi merupakan gabungan dari cita-cita institusi, di satu sisi, dan keinginan khalayak, pemirsa, dan pembaca, pada pihak lain (Abrar, 2011:36). Artinya ada mekanisme dan urutanurutan tertentu sebuah berita bisa dimuat atau diturunkan.

Salah satu unsur dominan dalam sebuah berita yang siap disajikan ke pembaca adalah pengetahuan redaktur. Ia mengolah data dan fakta yang diberikan reporter dari lapangan. Ibaratnya 
redaktur adalah memasak yang bahan bakunya didapatkan reporter di lapangan. Berita yang merupakan hasil olahan tentu saja tidak bisa begitu saja adanya. Ia adalah campur tangan yang dimiliki redaktur, termasuk pengetahuan.

Akhir-akhir ini, isu LGBT di surat kabar nasional cenderung meningkat. Banyak pro dan kontra. Perdebatan melingkupi beragam masalah seperti asal mula, pandangan agama, sosial budaya, hingga pandangan agama tentang LGBT. Perdebatan tersebut tentu saja mengandung banyak nilai berita yang wajib diperhatikan redaktur surat kabar. Bahkan secara sosiologis mengarah ke anarkistis karena berkaitan dengan keyakinan seseorang yang bersifat mutlak. Di sisi lain, isu LGBT ini mendapat tempat yang luas di ranah media internasional. Karena tidak ada media yang lepas dari hubungan internasional, isu LGBT ini akan memengaruhi redaktur koran dalam negeri, termasuk Koran Sindo.

Berdasarkan paparan di atas, penelitian ini mencoba memotret hubungan antara pengetahuan agama wartawan dengan pemberitaan LGBT di Koran Sindo. Wartawan dalam penelitian ini adalah level redaktur. Redaktur adalah wartawan yang mengolah hasil dari lapangan reporter. Biasanya, redaktur lebih senior, memiliki jam terbang lebih tinggi, dan pengalaman yang lebih luas daripada reporter di lapangan. Redaktur adalah karier tertinggi dari profesi wartawan. Ia yang menentukan sebuah berita bisa dimuat atau tidak pada sebuah surat kabar. Lebih spesifik lagi redaktur yang dimaksud adalah redaktur surat kabar yang bertiras nasional. Maksud berlevel nasional adalah yang memiliki jaringan produksi, distribusi, dan konsumsi di seluruh Indonesia, dalam pengertian kertas, bukan e-paper. Berdasarkan data SPSI (Serikat Penerbit Seluruh Indonesia), surat kabar Koran Sindo merupakan yang bertiras nasional.

Berdasarkan data Nilesen Media Index 2009, profil pembaca Koran Sindo terbesar adalah 54\% pembaca berusia 20-39 tahun. Jumlah keseluruhan pembaca Koran Sindo adalah 626.000. Jika dibandinghkan dengan Kompas, akan diperoleh perbandingan sebagai berikut 186.000 (30\%) merupakan pembaca Seputar Indonesia \& Kompas 440.000 (705) merupakan pembaca Seputar Indonesia saja. Ada 440.000 orang pembaca Seputar Indonesia yang tidak membaca Kompas. Secara demografi jumlah pembaca Koran Sindo di daerah terbagai sebagai berikut Bandung 10.000 pembaca. Surabaya ( 26.000), Jateng \& DIY ( 47.000), Makassar (23.000), Medan (18.000) dan Palembang (12.000) (Nilesen Media Index 2009 Wave 1). 


\section{KERANGKA PEMIKIRAN}

\section{Grand Theory}

Penelitian ini memiliki kerangka teori sebagai berikut. Teori sistem menjadi grand theory, organisasi media untuk middle range theory, dan agenda setting sebagai applaid theory-nya.

Sistem berasal dari bahasa Yunani, sistema, yang berarti suatu keseluruhan yang tersusun dari sekian banyak bagian. Ia satu kesatuan yang tidak terpisah satu sama lainnya. Masing-masing elemen atau sub-sistem saling terkait dan saling menguatkan. Menurut Littlejohn (1999), suatu sistem terdiri dari empat hal, yaitu:

1. Objek-objek. Objek adalah bagian-bagian, elemenelemen, atau variabelvariabel dari sistem. Mereka bisa jadi berbentuk fisik atau abstrak atau kedua-duanya, tergantung dari sifat sistem.

2. Atribut. Suatu sistem terdiri dari atribut-atribut, kualitas atau properti sistem itu dan objek-objeknya.

3. Hubungan internal, hubungan antara anggota sistem.

4. Lingkungan, suatu sistem memiliki suatu lingkungan. Mereka tidak hadir dalam suatu kevakuman, tetapi dipengaruhi oleh keadaan sekitarnya.

Ia melanjutkan sistem mempunyai beberapa sifat. Antara lain, pertama, keseluruhan dan interdependensi (wholeness and interdependence). Kedua, hierarki (hierarchy). Ketiga, peraturan sendiri dan control (self-regulation and control). Keempat, pertukaran dengan lingkungan (interchange with environment). Kelima, keseimbangan (balance). Keenam, perubahan dan kemampuan beradaptasi (change and adaptibity), dan terakhir, sama akhirnya (equifinality).

Teori sistem memiliki keterkaitan dengan dua teori lainnya, yakni, teori informasi dan sibernetika. Teori sistem dilahirkan dari pendekatan reduksionis yang dianut oleh ilmuilmu kealaman. Dalam teori sistem semuanya terkait jaringan, termasuk aspek komunikasi dan organisasi. Individu adalah bagian kelompok yang saling berkomunikasi dengan kelompok lain membentuk sistem yang lebih besar. Komunitas besar merupakan jaringan komunikasi kelompok-kelompok yang saling terhubung dan berinteraksi.

\section{Middle Range Theory}

Sementara itu, middle range theory dalam penelitian ini adalah organisasi media. Kegiatan produksi jurnalistik dikelola lembaga yang menganut prinsip-prinsip organisasi. Oleh karena mereka berada dalam media, ia disebut sebagai organisasi media. Organisasi media sebagai sebuah organisasi mempunyai iklim kerja yang khas. Ia dijaga setiap 
anggota organisasi dan itu memengaruh bagaimana mereka bekerja di dalamnya. Apa yang ada dalam organisasi media akan mengatur bagaimana orang-orang di dalamnya, mulai dari pemimpin redaksi, redaktur eksekutif, redaktur, asisten redaktur, hingga reporter bekerja dalam kegiatan jurnalisme. Struktur kerja organisasi media pun perlu dipahami tak hanya oleh tiap individu di dalam media tetapi juga oleh khalayak umum, gunanya untuk lebih dapat memahami fungsi dan peran pers.

Tidak semua peristiwa bisa dibuat berita. Semuanya tergantung sudut pandang (angle) yang mau diambil oleh redaksi yang keputusannya ditentukan oleh kebijakan redaksi (Tebba, 2005:150). Wartawan yang berada di lapangan (reporter) hanyalah mencari fakta dari sebuah peristiwa. Sedangkan editor hanyalah merapikan berita. Mereka tidak bisa menentukan berita yang dibuatnya ditampilkan dalam surat kabarnya. Sebab keputusan pemuatan berita ditentukan oleh kebijakan redaksi yang tercermin dalam rapat redaksi. Dengan demikian, kebijakan redaksi merupakan gabungan dari cita-cita institusi, di satu sisi, dan keinginan pembaca, pada pihak lain (Abrar, 2011:36). Artinya ada mekanisme dan urutan-urutan tertentu sebuah berita bisa dimuat seperti digambarkan di bawah ini.

\section{Applaid Theory Agenda Setting}

Dari beberapa asumsi mengenai efek komunikasi massa, satu yang bertahan dan terus berkembang adalah agenda setting. Teori ini menganggap media massa-dengan memberikan perhatian pada isu tertentu dan mengabaikan faktor yang lain--, memiliki pengaruh terhadap pendapat umum (opini publik). Orang akan cenderung mengetahui tentang hal-hal yang diberitakan dan menerima susunan prioritas yang diberikan media massa terhadap isu-isu yang berbeda.

Teori agenda setting pertama kali dikemukakan oleh Maxwell McComb dan DL Shaw dalam Public Opinion Quartely tahun 1972 berjudul Setting Function of Mass Media (Bungin, 2008:281). Keduanya mengatakan publik tidak hanya mempelajari berita-berita dan hal-hal lainnya melalui media massa, tetapi juga mempelajari seberapa besar arti penting diberikan kepada suatu isu atau topik dari cara media massa memberikan penekanan terhadap topik tersebut.

Dasar pemikiran agenda setting adalah di antara berbagai topik yang dimuat media massa, topik yang mendapat perhatian lebih banyak dari media massa akan menjadi lebih dekat bagi pembacanya. Berita akan dianggap penting dalam suatu periode. 
Sedangkan berita lain dikesampingkan. Griffin memungkas bahwa agenda setting adalah the pattern of news coverage across major print and broadcast media as measured by the prominance and length of stories (Griffin, 2009:360). Teori Agenda-Setting (Disarikan dari Griffin, EM, A'First Look at Communication Theory: Eight Edition, Mc. Graw Hill, New York, 2012) sangat berkaitan dengan komunikasi massa dan produksi berita. Maxwell McCombs dan Donald Shaw mengungkapkan bahwasanya Agenda-Setting adalah kemampuan media massa untuk mengirimkan arti penting sebuah isu dalam agenda berita mereka kepada agenda publik McCombs dan Shaw tidak menyatakan bahwa pegawai media cetak dan elektronik mempengaruhi khalayak secara langsung terkait suatu isu.

Reporter dalam pandangan McCombs dan Shaw memiliki independensi dan keberimbangan sebagai bentuk upaya menjaga reputasi mereka yang netral. Namun McCombs dan Shaw menyatakan bahwa kebanyakan orang melihat pada professional yang ada dibelakang berita untuk mencari petunjuk pada bagian mana fokus harus diberikan. Dengan ungkapan yang sederhana McCombs dan Shaw menyatakan bahwa kebanyakan orang memandang penting apa yang media anggap sebagai isu penting.
Media massa dalam dalam pandangan Bernard Cohen mungkin tidak terlalu berhasil dalam mendikte orang apa yang harus dipikirkan (what to think) namun media massa secara hebat berhasil mendikte audiens harus memikirkan tentang apa (what to think about).

Teori Agenda-Setting menawarkan sebuah hal yang menarik. Pada satu sisi teori ini memperkuat pandangan bahwa pers memiliki kekuatan yang besar namun di sisi lain mempertahankan pandangan bahwa individu memiliki kebebasan untuk memilih. Hal ini yang membedakan Teori AgendaSetting dengan teori-teori sebelumnya yang menganggap pers atau media massa sangat powerful dan audiens dianggap pasif. Teori Agenda Setting McCombs dan Shaw dibangun dari asumsi yang menyatakan bahwa ada hubungan sebab akibat antara konten media dengan persepsi khalayak.

Riset

berikutnya menunjukkan ada pengaruh yang kuat dari prioritas media yang menganggap suatu hal penting terhadap khalayak. Hal ini kemudian menunjukkan ada kecocokan antara agenda media dengan agenda publik. Kecocokan antara Agenda Media dan Agenda Publik. Agenda Media dapat didefinisikan sebagai pola peliputan berita yang dilakukan oleh media cetak maupun media elektronik sebagaimana diukur dari kemunculan 
dan durasi cerita atau isu. Sementara agenda publik didefinisikan sebagai isu-isu publik yang dianggap paling penting berdasarkan survei opini publik.

Sebetulnya dalam pandangan

Teori Agenda Setting, bukan pengaruh media yang menentukan tindakan khalayak secara linier, namun ada semacam hubungan sebab akibat yang terjadi. Pada satu titik media ((berita LGBT di Koran Sindo) mampu memengaruhi khalayak melalui agendanya, sehingga persepsi khalayak akan sama dengan persepsi yang dibangun oleh media massa. Namun apa yang dianggap penting oleh khalayak memengaruhi media massa pula sehingga apa yang ditampilkan oleh media massa (berita LGBT di Koran Sindo) merupakan refleksi dari apa yang khalayak anggap penting.

\section{METODE PENELITIAN}

Metode penelitian yang dipakai adalah survei yang meneliti dan mengambil sampel dalam satu populasi, yaitu redaktur Koran Sindo. Metode Survei kata Kerlinger (1997) seperti dikutip Sugiyono (2001:16) menyatakan penelitian yang dilakukan dalam populasi besar atau kecil. Juwono Tri Atmodjo (Modul kuliah Metode Penelitian Komunikasi , Magister Komunikasi Fakultas Ilmu Komunikasi Universitas Mercu Buana, Jakarta 2011 : 19) menambahkan, penelitian survei adalah suatu penelitian yang mengambil sampel dari suatu populasi dan menggunakan kuisioner sebagai alat pengumpul data yang pokok, lazimnya dengan menguji hipotesis. Metode survei sambung Mohamad Nazir menjelaskan bahwa metode survei membedah dan menguliti serta masalah-masalah serta pembenaran terhadap keadaaan dan praktikpraktik yang sedang berlangsung.

Data yang dikumpulkan dan dipelajari adalah data sampel dari populasi tersebut. Dari data sampel setelah diberi kuesioner akan diketahui hubungan kausalitas antara variabel bebas yaitu pengetahuan agama wartawan dan variabel terikat yaitu pemberitaan LGBT.

Populasi dalam pandangan Sugiyono (2006:89) adalah wilayah generalisasi yang terdiri atas objek/subjek yang mempunyai kualitas dan karakteristik tertentu yang ditetapkan oleh peneliti. Untuk dipelajari dan kemudian ditarik kesimpulannya. Populasi ini menurut Hamidi (2010:126), adalah mereka yang diberi kuesioner untuk dijawab atau diisi. Untuk itulah peneliti harus menentukan kriteria populasi yang akan diteliti.

Dalam penelitian ini, maka populasinya adalah wartawan yang menjabat sebagai redaktur di Koran Sindo, yang tertera dalam boks redaksi yang ada dalam setiap hari terbitan ketiga koran tersebut. 
Jumlah redaktur kelima Koran Sindo sebanyak 12 orang.

Sedangkan kata Tri Juwono Atmodjo (2010:126) sampel adalah bagian populasi yang diambil dan mewakili dari keseluruhan. Untuk menentukan jumlah sampel minimal dengan menggunakan rumus

$$
\begin{aligned}
& \mathrm{n}=\underline{\mathrm{N}} \\
& \mathrm{N} \cdot \mathrm{d} 2+1 . \\
& \mathrm{n} \text { adalah sampel } \\
& \mathrm{N} \text { adalah pupolasi } \\
& \mathrm{d} \text { adalah presisi. }
\end{aligned}
$$

Berdasarkan kerangka sampel itulah peneliti memberi orang-orang kuesioner untuk dijawab ${ }^{1}$. Yang perlu diperhatikan dalam pengambilan sampel adalah

1. Masalah, tujuan, dan rencana analisis

2. Tingkat "Homoginitas"/tingkat keseragaman populasi

3. Presisi yang dikehendaki (sampling error)

4. Penyebaran unit analisis

5. Tersedia/tidak sampling frame (daftar/kerangka sampel)

6. Kecukupan biaya, tenaga, dan waktu dsb (2010:132)

Dalam penelitian ini penulis memutuskan menggunakan teknik sampling jenuh yang termasuk pada non-probability sampling. Sampling jenuh kata Sugiyono (2006:95) adalah

1 Metode Penelitian dan Teori Komunikasi, Hamidi, UMM Press, Malang, 2010 : 132 teknik penentuan sampel yang semua anggota populasinya menjadi sampel. Dengan jumlah itu, peneliti yakin memiliki dana, waktu, dan tenaga yang cukup untuk menjadikan populasi sebagai sampel. Dengan demikian sampel jenuh ini berarti semua suara sampel adalah suara populasi. Begitu juga sebaliknya suara populasi adalah suara sampel.

Dalam penelitian ini tes statistik yang dipergunakan adalah statistik non parametrik. Penggunaan jenis statistik ini disebabkan jumlah sampel yang relatif sedikit data sehingga tidak membutuhkan asumsi-asumsi tentang sebaran data populasi. Datanya bersifat ordinal sehingga tidak membutuhkan normalisasi data. Hipotesisnya cukup dengan crosstab saja.

\section{HASIL DAN PEMBAHASAN}

\section{A. Karakteristik Responden}

Penelitian ini menggunakan teknik sampling jenuh (Sugiyono, 2009:124) karena populasinya kecil. Setelah penyebaran angket, terkumpul sebanyak 10 angket yang diisi oleh responden.

Selengkapnya, karakteristik responden disajikan di Tabel 4.I berikut ini: 
Tabel 1

Karakteristik Responden

\begin{tabular}{|l|l|l|l|}
\hline No & Karakteristik & \multicolumn{2}{l|}{ Jumlah (Orang) } \\
\hline 1 & \multirow{2}{*}{ Jenis Kelamin } & Laki-laki & 8 \\
\cline { 3 - 4 } & & Perempuan & 2 \\
\hline 2 & \multirow{2}{*}{ Usia } & 25-35 Tahun & 1 \\
\cline { 3 - 4 } & & 35-45 Tahun & 9 \\
\cline { 3 - 4 } & & $>45$ Tahun & 0 \\
\hline \multirow{2}{*}{3} & \multirow{2}{*}{ Pendidikan } & Sarjana & 7 \\
\cline { 3 - 4 } & & Pasca Sarjana & 3 \\
\hline 4 & \multirow{2}{*}{ Lama Kerja } & 2-4 Tahun & 1 \\
\cline { 3 - 4 } & & $>6$ Tahun & 9 \\
\hline
\end{tabular}

Sumber: Olahan Penelitian

Tabel di atas menunjukkan bahwa mayoritas responden adalah laki-laki, berusia 35-45 tahun, berpendidikan sarjana, dan telah bekerja lebih dari 6 tahun.

\section{B. Latar Belakang dan}

\section{Kegiatan Keagamaan}

\section{Responden}

Untuk mengetahui sejauh mana pemberitaan atas fenomena LGBT dituliskan di media, maka latar belakang mengenai kegiatan keagamaan wartawan menjadi hal yang menarik untuk dikaji. Hasil penelitian menunjukkan bahwa mayoritas responden (6 orang) tidak pernah mengenyam pendidikan agama. Sebanyak 6 responden tidak rutin mengikuti kajian agama, dan 6 responden dapat membaca kitab sucinya dengan baik.

\section{Pengetahuan Agama dan Pemberitaan Atas Fenomena LGBT}

Bagian ini akan membahas pengetahuan agama responden dan pemberitaan terhadap LGBT. Pembahasannya meliputi aspek keimanan, kehidupan antar manusia, aspek norma, serta aspek etika dan moral. Untuk pemberitaan, aspek yang diteliti adalah kelengkapan berita dan penempatan tulisan.

Kemudian, untuk mendapatkan interpretasi pembobotan, maka harus diketahui dahulu nilai tertinggi (X) dan nilai terendah (Y) untuk item penilaian dengan rumus berikut ini:

$\mathrm{X}=$ Skor tertinggi likert $\mathrm{x}$ jumlah responden

$\mathrm{Y}=$ Skor terendah likert $\mathrm{x}$ jumlah responden

Dengan demikian, $\mathrm{X}$ adalah 40, dan Y adalah 10. Penilaian interpretasi responden terhadap butir pertanyaan kuesioner adalah hasil nilai yang dihasilkan dengan menggunakan rumus Index $\%$.

Rumus Index $\%=($ Total Skor / X) x 100 
Karena penelitian ini digunakan. Berikut kriteria menggunakan skala likert, maka interpretasi skornya berdasarkan dari dibuat juga kategori penilaian interval terendah $0 \%$ hingga berdasarkan besarnya skala yang tertinggi $100 \%$

Tabel 2

Persentase Nilai

\begin{tabular}{|l|l|}
\hline \multicolumn{1}{|c|}{ Jawaban } & \multicolumn{1}{c|}{ Keterangan } \\
\hline $0 \%-24.99 \%$ & Sangat Tidak Setuju, Buruk atau Kurang Sekali \\
\hline $25 \%-49.99 \%$ & Tidak Setuju atau Kurang Baik \\
\hline $50 \%-74,99 \%$ & Setuju, Baik atau Suka \\
\hline $75 \%-100 \%$ & Sangat (Setuju, Baik, Suka) \\
\hline
\end{tabular}

\section{Aspek keimanan}

Angket untuk aspek keimanan terdiri atas 6 butir pertanyaan. Hasilnya disajikan di tabel berikut ini:

Tabel 3

Skor Aspek Keimanan

\begin{tabular}{|l|r|r|r|r|r|r|}
\hline & & $\begin{array}{c}\text { Minimu } \\
\mathrm{m}\end{array}$ & $\begin{array}{r}\text { Maximu } \\
\mathrm{m}\end{array}$ & \multicolumn{1}{c|}{ Sum } & Mean & $\begin{array}{c}\text { Std. } \\
\text { Deviation }\end{array}$ \\
\hline XA1 & 10 & 4 & 4 & 40 & 4.00 & .000 \\
XA2 & 10 & 1 & 3 & 16 & 1.60 & .843 \\
XA3 & 10 & 1 & 3 & 16 & 1.60 & .843 \\
XA4 & 10 & 1 & 4 & 27 & 2.70 & 1.059 \\
XA5 & 10 & 1 & 4 & 34 & 3.40 & .966 \\
XA6 & 10 & 1 & 2 & 16 & 1.60 & .516 \\
Valid N & 10 & & & & & \\
(listwise) & & & & & \\
\hline
\end{tabular}

Interpretasi pembobotan untuk kriteria keimanan disajikan di tabel berikut ini:

Tabel 4

Interpretasi Pembobotan Pengetahuan keimanan

\begin{tabular}{|c|c|c|}
\hline Pertanyaan & Skor & Bobot (\%) \\
\hline XA1 & 40 & 100 \\
\hline XA2 & 16 & 40 \\
\hline XA3 & 16 & 40 \\
\hline XA4 & 27 & 67,5 \\
\hline XA5 & 34 & 85 \\
\hline XA6 & 16 & 40 \\
\hline Rerata & & 55,4 \\
\hline
\end{tabular}

Karena nilai bobot mempunyai skor 55,4 maka dapat dikatakan bahwa responden memiliki pengetahuan yang baik terkait dengan aspek keimanan. 


\section{Aspek Kehidupan Antar Manusia}

Angket untuk aspek pengetahuan kehidupan antar manusia terdiri atas empat butir pertanyaan. Hasilnya disajikan di tabel berikut ini:

Tabel 5

Skor Aspek Hubungan Antar Manusia

\begin{tabular}{|l|r|r|r|r|r|r|}
\hline & & $\begin{array}{c}\text { Minimu } \\
\mathrm{m}\end{array}$ & $\begin{array}{c}\text { Maximu } \\
\mathrm{m}\end{array}$ & \multicolumn{1}{c|}{ Sum } & Mean & $\begin{array}{c}\text { Std. } \\
\text { Deviation }\end{array}$ \\
\hline XB1 & 10 & 4 & 4 & 40 & 4.00 & .000 \\
XB2 & 10 & 3 & 4 & 36 & 3.60 & .516 \\
XB3 & 10 & 1 & 4 & 32 & 3.20 & 1.033 \\
XB4 & 10 & 3 & 4 & 36 & 3.60 & .516 \\
Valid N & 10 & & & & & \\
(listwise) & & & & & & \\
\hline
\end{tabular}

Interpretasi pembobotan untuk aspek hubungan antar manusia disajikan di tabel berikut ini:

Tabel 6

Interpretasi Pembobotan Hubungan Antar Manusia

\begin{tabular}{|c|c|c|}
\hline Pertanyaan & Skor & Bobot $(\boldsymbol{\%})$ \\
\hline XB1 & 40 & 100 \\
\hline XB2 & 36 & 90 \\
\hline XB3 & 32 & 80 \\
\hline XB4 & 36 & 90 \\
\hline Rerata & & $\mathbf{9 0}$ \\
\hline
\end{tabular}

Karena nilai bobot mempunyai skor 90, maka dapat dikatakan bahwa responden memiliki pengetahuan yang sangat baik terkait dengan hubungan antar manusia.

\section{Aspek Norma}

Angket untuk aspek norma terdiri atas tiga butir pertanyaan. Hasilnya disajikan di tabel berikut ini:

Tabel 7

Skor Aspek Norma

\begin{tabular}{|l|r|r|r|r|r|r|}
\hline & & $\begin{array}{c}\text { Minimu } \\
\mathrm{m}\end{array}$ & $\begin{array}{c}\text { Maximu } \\
\mathrm{m}\end{array}$ & Sum & Mean & $\begin{array}{c}\text { Std. } \\
\text { Deviation }\end{array}$ \\
\hline XC1 & 10 & 1 & 4 & 31 & 3.10 & 1.197 \\
XC2 & 10 & 1 & 4 & 31 & 3.10 & .876 \\
XC3 & 10 & 1 & 4 & 26 & 2.60 & 1.075 \\
\hline
\end{tabular}


Valid N

Interpretasi pembobotan untuk kriteria pemgetahuan norma disajikan di Tabel 8 berikut in:

Tabel 8

Interpretasi Pembobotan Aspek Norma

\begin{tabular}{|c|c|c|}
\hline Pertanyaan & Skor & Bobot (\%) \\
\hline XC1 & 31 & 92,5 \\
\hline XC2 & 31 & 92,5 \\
\hline XC3 & 26 & 65 \\
\hline Rerata & & $\mathbf{8 3 , 3}$ \\
\hline
\end{tabular}

Karena nilai bobot mempunyai skor 83,3 maka dapat dikatakan bahwa responden memiliki pengetahuan yang sangat baik terkait dengan norma.

\section{Aspek Etika dan Moral}

Angket untuk aspek norma terdiri atas empat butir pertanyaan. Hasilnya disajikan di tabel 9 berikut ini:

Tabel 9

Skor Aspek Etika dan Moral

\begin{tabular}{|l|r|r|r|r|r|r|}
\hline & & $\begin{array}{c}\text { Minimu } \\
\mathrm{m}\end{array}$ & $\begin{array}{c}\text { Maximu } \\
\mathrm{m}\end{array}$ & \multicolumn{1}{c|}{ Sum } & Mean & $\begin{array}{c}\text { Std. } \\
\text { Deviation }\end{array}$ \\
\hline XD1 & 10 & 1 & 4 & 25 & 2.50 & .972 \\
XD2 & 10 & 1 & 4 & 27 & 2.70 & .949 \\
XD3 & 10 & 1 & 4 & 31 & 3.10 & 1.101 \\
XD4 & 10 & 1 & 4 & 33 & 3.30 & .949 \\
Valid N & 10 & & & & & \\
(listwise) & & & & & & \\
\hline
\end{tabular}

Interpretasi pembobotan untuk aspek etika dan moral disajikan di tabel 10 berikut ini:

Tabel 10

Interpretasi Pembobotan Aspek Etika dan Moral

\begin{tabular}{|c|c|c|}
\hline Pertanyaan & Skor & Bobot (\%) \\
\hline XD1 & 25 & 62,5 \\
\hline XD2 & 27 & 67,5 \\
\hline XD3 & 31 & 77,5 \\
\hline XD4 & 33 & 82,5 \\
\hline Rerata & & $\mathbf{7 2 , 5}$ \\
\hline
\end{tabular}

Karena nilai bobot

mempunyai skor 72,5 maka dapat 
dikatakan bahwa responden memiliki pengetahuan yang baik terkait dengan etika dan moral.

Mengacu pada hasil perhitungan sebelumnya, maka dapat dibuat resume mengenai pengetahuan agama para wartawan di Harian Sindo sebagai berikut:

Tabel 11

Pengetahuan Agama

\begin{tabular}{|c|l|c|}
\hline No & \multicolumn{1}{|c|}{ Kegiatan } & Bobot \\
\hline 1 & Pengetahuan keimanan & 55,4 \\
\hline 2 & Kehidupan antar manusia & 90 \\
\hline 3 & Pengetahuan norma & 83,3 \\
\hline 4 & Aspek etika dan moral & 72,5 \\
\hline & Rerata & $\mathbf{7 5 , 3}$ \\
\hline
\end{tabular}

Dengan nilai bobot rata-rata sebesar 75,3, maka dapat dikatakan bahwa pengetahuan agama redaktur di Harian Sindo adalah baik.

\section{Pemberitaan tentang LGBT di Harian Sindo}

1. Kelengkapan Berita

Angket untuk kelengkapan berita terdiri atas 5 butir pertanyaan. Hasilnya disajikan di tabel 4.12 berikut ini:

Tabel 12

Kelengkapan Berita

\begin{tabular}{|l|r|r|r|r|r|r|}
\hline & & $\begin{array}{c}\text { Minimu } \\
\mathrm{m}\end{array}$ & $\begin{array}{r}\text { Maximu } \\
\mathrm{m}\end{array}$ & Sum & Mean & $\begin{array}{c}\text { Std. } \\
\text { Deviation }\end{array}$ \\
\hline YA1 & 10 & 2 & 4 & 35 & 3.50 & .707 \\
YA2 & 10 & 2 & 4 & 35 & 3.50 & .707 \\
YA3 & 10 & 3 & 4 & 35 & 3.50 & .527 \\
YA4 & 10 & 1 & 3 & 22 & 2.20 & .789 \\
YA5 & 10 & 1 & 4 & 28 & 2.80 & .789 \\
Valid N & 10 & & & & & \\
(listwise) & & & & & \\
\hline
\end{tabular}

Interpretasi pembobotan untuk kriteria kelengkapan berita disajikan di tabel berikut ini:

Tabel 13

Interpretasi Pembobotan Kelengkapan Berita

\begin{tabular}{|c|c|c|}
\hline Pertanyaan & Skor & Bobot (\%) \\
\hline YA1 & 35 & 87.5 \\
\hline YA2 & 35 & 87.5 \\
\hline YA3 & 35 & 87.5 \\
\hline YA4 & 22 & 55 \\
\hline YA5 & 28 & 70 \\
\hline Rerata & & $\mathbf{7 7 . 5}$ \\
\hline
\end{tabular}


Karena nilai bobot mempunyai skor 77,5 maka dapat dikatakan bahwa responden dalam menulis pemberitaan tentang LGBT, telah memenuhi unsur kelengkapan berita dengan sangat baik.

\section{Penempatan Tulisan}

Angket untuk penempatan tulisan terdiri atas 6 butir pertanyaan. Hasilnya disajikan di tabel 4.13 berikut ini:

Tabel 14

Penempatan Tulisan

\begin{tabular}{|l|r|r|r|r|r|r|}
\hline & & $\begin{array}{c}\text { Minimu } \\
\mathrm{m}\end{array}$ & $\begin{array}{c}\text { Maximu } \\
\mathrm{m}\end{array}$ & \multicolumn{1}{c|}{ Sum } & Mean & $\begin{array}{c}\text { Std. } \\
\text { Deviation }\end{array}$ \\
\hline YB1 & 10 & 1 & 3 & 21 & 2.10 & .876 \\
YB2 & 10 & 1 & 4 & 21 & 2.10 & .994 \\
YB3 & 10 & 1 & 3 & 25 & 2.50 & .707 \\
YB4 & 10 & 1 & 3 & 19 & 1.90 & .568 \\
YB5 & 10 & 1 & 3 & 16 & 1.60 & .699 \\
YB6 & 10 & 1 & 3 & 22 & 2.20 & .919 \\
Valid N & 10 & & & & & \\
(listwise) & & & & & & \\
\hline
\end{tabular}

Interpretasi pembobotan untuk kriteria penempatan tulisan disajikan di tabel 13 berikut ini:

Tabel 15

Interpretasi Pembobotan Penempatan Tulisan

\begin{tabular}{|c|c|c|}
\hline Pertanyaan & Skor & Bobot (\%) \\
\hline YB1 & 21 & 52.5 \\
\hline YB2 & 21 & 52.5 \\
\hline YB3 & 25 & 62.5 \\
\hline YB4 & 19 & 47.5 \\
\hline YB5 & 16 & 40 \\
\hline YB6 & 22 & 55 \\
\hline Rerata & & $\mathbf{5 1 . 6}$ \\
\hline
\end{tabular}

Karena nilai bobot mempunyai skor 51.6 maka dapat dikatakan bahwa responden dalam menulis pemberitaan tentang LGBT, telah memenuhi unsur penempatan tulisan dengan baik.
Mengacu pada hasil perhitungan sebelumnya, maka dapat dibuat resume mengenai pemberitaan tentang LGBT para wartawan harian Sindo sebagai berikut:

Tabel 16

Pemberitaan tentang LGBT

\begin{tabular}{|l|l|l|}
\hline No & Kegiatan & Bobot \\
\hline
\end{tabular}




\begin{tabular}{|c|l|c|}
\hline 1 & Kelengkapan Berita & 77.5 \\
\hline 2 & Penempatan Tulisan & 51.6 \\
\hline & Rerata & $\mathbf{6 4 . 5 5}$ \\
\hline
\end{tabular}

Dengan nilai bobot rata-rata sebesar 64.55, maka dapat dikatakan bahwa pemberitaan tentang LGBT wartawan di Harian Sindo cukup baik dengan mengikuti kaidah kelengkapan berita dan penempatan tulisan.

\section{E. Hubungan Antara Latar Belakang dan Kegiatan Keagamaan dengan Pengetahuan Agama}

Untuk mengetahui apakah pengetahuan agama responden dipengaruhi oleh faktor pendidikan agama, rutinitas mengikuti pengajian, dan kemampuan membaca kitab suci atau tidak, maka penelitian ini akan menguji faktor-faktor tersebut melalui tabulasi silang.

Hubungan antara faktorfaktor tersebut dengan pengetahuan agama responden disajikan berikut ini:
1. Hubungan

Antara

Pendidikan

Agama

dengan

Pengetahuan

Agama

Hipotesis yang dibuat untuk hubungan ini adalah sebagai berikut:

$\mathrm{H}_{0}=$ Tidak ada hubungan antara pendidikan agama dengan pengetahuan agama

$\mathrm{H}_{\mathrm{a}}=$ Ada hubungan antara pendidikan agama dengan pengetahuan agama

Adapun hasil uji chi square untuk hubungan ini disajikan sebagai berikut:

\section{Tabel 17}

Hasil Chi Square Pendidikan dengan Pengetahuan

\begin{tabular}{|l|l|l|l|}
\hline & & & $\begin{array}{l}\text { Asymptotic } \\
\text { Significance } \\
\text { (2-sided) }\end{array}$ \\
\hline Palue & df & .340 \\
Likelihood Ratio & $7.917^{\mathrm{a}}$ & 7 & .153 \\
Linear-by-Linear & 10.688 & 7 & .405 \\
Association & .692 & 1 & \\
N of Valid Cases & 10 & & \\
\hline
\end{tabular}

a. 16 cells (100.0\%) have expected count less than 5. The minimum expected count is. 
Berdasarkan tabel di atas, karena Asymp. Sig memiliki nilai 0.340 , berarti lebih besar dari taraf siginifikansi, yakni 0.05, maka $\mathrm{H}_{0}$ diterima dan $\mathrm{H}_{\mathrm{a}}$ ditolak. Artinya, tidak ada hubungan antara pendidikan agama dengan pengetahuan agama responden.

2. Hubungan Antara Rutinitas Pengajian Mengikuti dengan
Hipotesis yang dibuat untuk hubungan ini adalah sebagai berikut: $\mathrm{H}_{0}=$ Tidak ada hubungan antara rutinitas mengikuti pengajian dengan pengetahuan agama $\mathrm{H}_{\mathrm{a}}=$ Terdapat hubungan antara rutinitas mengikuti pengajian dengan pengetahuan agama

Adapun hasil uji chi square untuk hubungan ini adalah sebagai berikut:

Tabel 18

Hubungan Rutinitas dengan Pengetahuan Agama

\begin{tabular}{|c|c|c|c|}
\hline & Value & df & $\begin{array}{l}\text { Asymptotic } \\
\text { Significance } \\
(2 \text {-sided })\end{array}$ \\
\hline Pearson Chi-Square & $7.917^{\mathrm{a}}$ & 7 & .340 \\
\hline Likelihood Ratio & 10.688 & 7 & .153 \\
\hline Linear-by-Linear & 1.338 & 1 & .247 \\
\hline $\begin{array}{l}\text { Association } \\
\mathrm{N} \text { of Valid Cases }\end{array}$ & 10 & & \\
\hline
\end{tabular}

a. 16 cells (100.0\%) have expected count less than 5. The minimum expected count is 40.

Berdasarkan tabel di atas, karena Asymp. Sig memiliki nilai 0.340 , berarti lebih besar dari taraf siginifikansi, yakni 0.05, maka $\mathrm{H}_{0}$ diterima dan
$\mathrm{H}_{\mathrm{a}}$ ditolak. Artinya, tidak ada hubungan antara rutinitas mengikuti pengajian/taklim dengan pengetahuan agama responden. 
3. Hubungan Antara

Kemampuan Membaca kitab

suci dengan Pengetahuan

Agama

Hipotesis yang dibuat untuk hubungan ini adalah sebagai berikut:

$\mathrm{H}_{0}=$ Tidak ada hubungan

antara kemampuan membaca
Alquran dengan pengetahuan agama

$\mathrm{Ha}=$ Terdapat hubungan antara kemampuan membaca Alquran dengan pengetahuan agama

Adapun hasil uji chi square untuk hubungan ini adalah sebagai berikut:

Tabel 19

Hubungan Baca Kitab Suci dengan Pengetahuan Agama

\begin{tabular}{|c|c|c|c|}
\hline & Value & df & $\begin{array}{c}\text { Asymptotic } \\
\text { Significance } \\
\text { (2-sided) }\end{array}$ \\
\hline Pearson Chi-Square & $7.917^{\mathrm{a}}$ & 7 & .340 \\
\hline Likelihood Ratio & 10.688 & 7 & .153 \\
\hline Linear-by-Linear & 1.392 & 1 & .238 \\
\hline $\begin{array}{l}\text { Association } \\
\mathrm{N} \text { of Valid Cases }\end{array}$ & 10 & & \\
\hline
\end{tabular}

a. 16 cells (100.0 have expected count less than 5. The

minimum expected count is.40.

Berdasarkan tabel di atas, karena Asymp. Sig memiliki nilai 0.340 , berarti lebih besar dari taraf siginifikansi, yakni 0.05 , maka $\mathrm{H}_{0}$ diterima dan $\mathrm{H}_{\mathrm{a}}$ ditolak. Artinya, tidak ada hubungan antara kemampuan membaca Alquran dengan pengetahuan agama responden.

Mengacu pada ketiga hubungan di atas, maka dapat dikatakan bahwa tidak adanya hubungan antara faktor pendidikan agama, rutinitas mengikuti pengajian, dan kemampuan membaca Alquran dengan pengetahuan agama responden. Ketiadaan hubungan tersebut karena tidak adanya faktor apakah para responden sudah lama mengikuti pendidikan agama, sudah lama mengikuti pengajian, atau sudah lama mengenal dan memaknai Alquran. Dengan demikian, faktor pernah saja mengikuti pendidikan agama, rutin mengikuti pengajian, dan paham Alquran tidak berbanding lurus dengan 
pengetahuan agama

responden.

F. Hubungan

Pengetahuan

Antara

Agama dengan Pemberitaan

tentang LGBT

Rumusan hipotesis penelitian ini disarikan dalam tabel berikut:

Tabel 20

Hipotesis Hubungan Pengetahuan Agama dengan Pemberitaan tentang

LGBT

\begin{tabular}{|l|l|}
\hline Hipotesis Penelitian & Hipotesis Statistik \\
\hline $\begin{array}{l}\text { Terdapat hubungan antara } \\
\text { pengetahuan agama } \\
\text { dengan pemberitaan } \\
\text { tentang LGBT }\end{array}$ & $\begin{array}{l}\text { Ho: Tidak terdapat hubungan antara pengetahuan } \\
\text { agama dengan pemberitaan tentang LGBT }\end{array}$ \\
\cline { 2 - 2 } & $\begin{array}{l}\text { Ha: Tterdapat hubungan antara pengetahuan agama } \\
\text { dengan pemberitaan tentang LGBT }\end{array}$ \\
\hline
\end{tabular}

Karena penelitian ini menggunakan data ordinal, maka uji statistiknya memakai uji Chi square. Adapun hasil pengujian hipotesis adalah:

Tabel 21

Hasil Uji Hipotesis

\begin{tabular}{|l|r|r|r|}
\hline & \multicolumn{1}{|c|}{ Value } & df & $\begin{array}{c}\text { Asymptotic } \\
\text { Significance } \\
\text { (2-sided) }\end{array}$ \\
\hline Pearson Chi-Square & $52.500^{\mathrm{a}}$ & 42 & .129 \\
Likelihood Ratio & 33.915 & 42 & .808 \\
Linear-by-Linear & 1.010 & 1 & .315 \\
Association & 10 & & \\
N of Valid Cases & & \\
\hline
\end{tabular}

a. 56 cells $(100.0 \%)$ have expected count less than 5 . The minimum expected count is .10 .

Berdasarkan panduan SPSS, untuk mengambil keputusan dari tabel di atas, dapat digunakan 2 cara:

1. Koefisien korelasi dibandingkan dengan nilai $\mathbf{r}$ tabel

a. Bila koefisien korelasi $>\mathbf{r}$

tabel, maka ada korelasi

yang signifikan (Ha

diterima) b. Bila koefisien korelasi < $r$ tabel, maka tidak ada korelasi yang signifikan ( Ho diterima)

2. Melihat signifikance (Sig)

a. Bila nilai sig $<0.05$, maka ada korelasi yang signifikan (Ha diterima)

b. Bila nilai sig >0.05, maka tidak ada korelasi 
yang signifikan (Ho diterima)

Karena nilai korelasi di atas < $r$ tabel ( $r$ tabel untuk $\mathrm{N}=10$ dengan tingkat kepercayaan $1 \%$ adalah 0.257), dapat dikatakan bahwa $\mathrm{H}_{0}$ diterima. Dengan demikian, tidak terdapat hubungan antara pengetahuan agama dengan pemberitaan tentang LGBT.

Media massa dewasa ini telah menempatkan dirinya sebagai institusi yang telah memiliki peran yang cukup signifikan dalam perubahan sosial masyarakat. Peran besar tersebut tidak terlepas dari posisi keredaksian yang membawa kepentingan masyarakat banyak atas kebutuhan informasi yang berimbang dan adil.

Kemampuan redaksi untuk membawa kepentingan masyarakat tersebut tergantung pada isu-isu yang tengah berkembang. Pada isu yang sensitif, misalnya saja tentang LGBT, posisi wartawan sebagai ujung tombak redaksi bergantung pada di mana wartawan tersebut bekerja. Isu pemberitaan LGBT di bermula pada kemunculan LGBT di ruang publik. Kehadiran LGBT diruang publik menimbulkan pro kontra pada pemberitaan LGBT di Indonesia.

Beberapa penelitian terdahulu secara kualitatif, misalnya yang dilakukan oleh Nirwanto (2016), Zuhra (2013), Satrio (2013) menemukan bahwa media mempunyai posisi kuat dalam membawa arah pemberitaan, di mana ideologi media memengaruhi pemberitaan tentang isu LGBT tersebut.

Pada dasarnya, terkait dengan isu-isu publik yang sensitif, pers nasional secara umum dapat dibagi atas tiga posisi besar (Priyambodo, 2014), yakni: 1) ikut menentukan pendapat publik opini mengikuti pendapat publik; 3) menjaga eksistensi. Pada ketiga posisi itulah, media menentukan ke arah mana isu LGBT akan bermuara.

Media yang akan mengangkat isu sensitif seperti LGBT harus taat dalam koridor yang telah ditentukan Undang-undang Pers Nomor 40 Tahun 1999. Di Pasal 6 UU tersebut mengamanatkan bahwa pers nasional melaksanakan peranan memenuhi hak masyarakat untuk mengetahui, menegakkan nilai-nilai dasar demokrasi, dan Hak Asasi Manusia, serta menghormati kebhinekaan. Mengembangkan pendapat umum berdasarkan informasi yang tepat, akurat dan benar.

Selanjutnya, dalam Kode Etik yang dirumuskan 29 organisasi profesi pada 2006, pasal 1 mengamanatkan "Wartawan Indonesia bersikap independen, menghasilkan berita yang akurat, berimbang, dan tidak beritikad buruk." Sedangkan pada Pasal 8: "Wartawan Indonesia tidak menulis atau menyiarkan berita berdasarkan 
prasangka atau diskriminasi terhadap seseorang atas dasar perbedaan suku, ras, warna kulit, agama, jenis kelamin, dan bahasa serta tidak merendahkan martabat orang lemah, miskin, sakit, cacat jiwa atau cacat jasmani." Pada bagian penafsiran pasal ini dijelaskan, prasangka adalah anggapan yang kurang baik mengenai sesuatu sebelum mengetahui secara jelas dan diskriminasi adalah pembedaan perlakuan.

Pedoman Prilaku Penyiaran Standar Program Siaran (P3SPS) 2012, Bab XI pasal 15 ayat 1, mengamatkan tentang perlindungan kepada orang dan kelompok masyarakat tertentu, termasuk didalamnya, "Orang atau kelompok dengan orientasi seksual atau identitas gender tertentu." Pada ayat 2 mengatur lembaga penyiaran tidak boleh menyiarkan atau menyajikan program yang menertawakan, menghina atau merendahkan kelompok masyarakat, termasuk di dalamnya orang atau kelompok dengan orientasi seksual atau identitas gender tertentu. Pada BAB XVIII P3SPS juga menekankan lembaga penyiaran mengedepankan Prinsip-Prinsip Jurnalistik. Di antaranya menjunjung prinsip keberimbangan, adil, tidak beritikad buruk dan lain-lain.

Penelitian ini menyoroti pengaruh pengetahuan agama redaksi terhadap pemberitaan tentang LGBT.
Hasil penelitian menunjukkan pengetahuan agama awak redaksi tidak dipengaruhi oleh pendidikan agama secara khusus (misalnya pernah masuk pesantren atau madrasah), tidak dipengaruhi oleh rutinitas pengajian/taklim yang diikuti oleh responden, serta tidak dipengaruhi apakah responden dapat membaca Alquran dengan baik atau tidak.

Hasil penelitian ini menunjukkan bahwa tidak ada pengaruh antara pendidikan agama, rutinitas mengikuti kegiatan keagamaan, dan kemampuan mambaca kitab suci dengan pengetahuan agama. Di samping itu, tidak ada pengaruh antara pengetahuan agama responden dengan pemberitaan mengenai isu LGBT. Dengan demikian, posisi latar belakang keagamaan responden sama sekali tidak memengaruhi pemberitaan tentang isu tersebut.

Hal ini dapat dipahami karena wartawan dalam memandang sebuah peristiwa dipengaruhi oleh bagaimana referensi yang memotivasinya untuk menerjemahkan peristiwa ke dalam konstruksi kebahasaan untuk diproduksi menjadi berita. Wartawan di Koran Sindo menerjemahkan referensi tersebut sebagai keleluasaan untuk menyampaikan berita mengenai isu LGBT sesuai dengan norma dan kaidah jurnalistik 
tanpa dihalangi oleh preferensi individual.

Faktor personal wartawan dalam memandang peristiwa apakah penting atau tidak penting untuk diberitakan adalah hal yang urgen untuk menjadi perhatian. Hal ini dikarenakan wartawan tak terlepas dari kondisi mereka yang memiliki kepribadian dan latar belakang yang berbeda-beda dalam memandang peristiwa yang terjadi di sekitarnya. Wartawan dalam melihat peristiwa memiliki kerangka berpikir tertentu meski keberadaan mereka dianggap akan menulis objektif sesuai dengan apa yang didiktekan mereka atau yang muncul dipermukaan saja. Meskipun demikian, dalam penelitian ini, hal-hal tersebut tidak menjadi variabel yang signifikan. Artinya, di Koran Sindo, wartawan tetap mampu menjaga objektivitasnya. Pemberitaan untuk isu-isu yang sensitif seperti kasus LGBT pun dianggap wartawan di Koran Sindo sebagai isu yang biasa.

\section{KESIMPULAN}

Berdasarkan penelitian yang telah dilakukan, maka dapat ditarik simpulan sebagai berikut:

1. Pengetahun agama para responden tidak dipengaruhi oleh pendidikan agama (pesantren/medrasah), rutinitas mengikuti kegiatan keagamaan dan pemahaman atas kitab suci..

2. Responden mempunyai pengetahuan yang tinggi menyangkut aspek pengetahuan agama. Hal ini terbukti dari rerata skor 17 item pertanyaan yang mampu melewati bobot standar 75 .

3. Responden juga punya sikap yang cukup objektif atas pemberitaan tentang LGBT, yang dibuktinya dari tingginya skor kelengkapan berita, yakni 77.5, meskipun skor untuk penempatan tulisan berada pada nilai ratarata.

4. Tidak terdapat pengaruh antara pengetahuan agama para responden dengan pemberitaan mengenai LGBT. Hal ini terbukti dengan uji hipotesis yang secara statistik menerima Ho dan menolak Ha.

\section{DAFTAR PUSTAKA}

Abrar, Ana Nadhya,. 2011. Analisis Pers; Teori dan Praktek, Cahaya Atma Pustaka, Yogyakarta

Bungin, Burhan, 2008. Konstruksi Realitas Media Massa;Kekuatan Pengaruh Media Massa, Iklan Televisi, dan Keputusan Konsumen Serta Kritik Terhadap Peter L. Berger dan Thomas 
Luckmann, Kencana Prenada

Media Group, Jakarta

Griffin, EM. 2009. A Firtst Look at Communicatin, $7^{\text {th }}$, McGraw-Hill, New York

Jowono, Tri Atmojo. 2011. Modul kuliah Metode Penelitian Komunikasi, Magister Komunikasi Fakultas Ilmu Komunikasi Universitas Mercu Buana, Jakarta

Kriyanto, Rachmat. 2007. Teknik Praktis Riset Komunikasi, Kencana, Jakarta

Littlejohn, Stephen W, and Karen A. Foss. 1999. Theories of Human Communication, 6th Ed., Belmont CA, Wadsworth Publishing

Malo, Manasse. 1986 Metode Penelitian Sosial, Kaunika, UI, Jakarta

Nazir, Mohamad. 1983. Metode Penelitian, Balai Aksara, Jakarta

Nirwanto, Gisela Dea. 2016. Pembingkaian Berita Pro Kontra LGBT di Laman Topik Pilihan Kompas.com. Jurnal E-Komunikasi, Vol. 4. No.1 Tahun 2016

Romli, Asep Saeful. 2005. Jurnalistik Praktis, Edisi Revisi, Remaja Rosdakarya, Bandung

Satrio, F.Xaverius Cornelissen. 2013. Interaksi Kaum Lesbian dan Jurnalis dalam Pemberitaan Mengenai Lesbian di Tribun Jogja.com (Studi Deskriptif Kualitatif Mengenai Interaksi Kaum Lesbian dan Jurnalis dalam Pemberitaan Kaum

Lesbian di Tribun

Jogja.com). E-Journal UAJY, Vol. 4 No. 2, 2013

Sugiyono, Penelitian Kualitatif, Kuantitatif, dan R\&D, 2006. Alfabeta, Bandung

Tebba, Sudirman, 2005. Jurnalistik Baru, Jakarta. Kalam Indonesia, Jakarta

Uchjana, Onong Effendy. 1990. Ilmu Komunikasi Teori dan Praktek, PT. Remaja Rosda Karya, Bandung

Wan Ulfa Nur Zuhra. 2013. Citra Homoseksual dalam Media Massa Online Nasional (Analisis Framing tentang Citra Homoseksual dalam Tempo.co dan Republika Online). Jurnal Komunikasi Flow, Vol 1, No 3 (2013)

\section{Sumber Lain}

http://www.spsindonesia.org/ http://www.statistikian.com/2013/01/ transformasi-data.html

Koran Tempo, 24 September 2010 Priyambodo RH. 2014. Kompetensi Wartawan dalam Pemberitaan Pemilu, tersedia pada; [http://www.lpds.or.id/index.php?opt ion $=$ com_content \&view $=$ article $\& i d=$ 698:kompetensi-wartawan-dalampemberitaanpemilu\&catid=14:berita-lpds] diunduh 15 Januari 2018 Nilesen Media Index 2009 Wave 1 